\title{
Use of mixed methods in road landscape perception studies: an example from Latvia
}

\author{
Kristīne Vugule ${ }^{1}$, Ilze Stokmane ${ }^{2}$, Simon Bell ${ }^{3}$ \\ ${ }^{1,2,3}$ Latvia University of Life Sciences and Technologies, Latvia \\ ${ }^{3}$ Estonian University of Life Sciences, Estonia
}

\begin{abstract}
We see, use and interact with different type of landscape every day. One of the important types is the road landscape we encounter during travel, whether a business trip, vacation or just on the way to and from home. Such landscapes can often help to introduce us to new regions or invite us to explore the surrounding areas because we partly experience the world around us from the road. Road landscapes combine important aspects of road and transport infrastructure as well as the quality of life of local people, traffic safety and tourism development. Road landscape development concerns both landowners and road users, each of whom might have different interests and understanding about possible landscape development and its consequences. Therefore, it is important to plan, discuss, present, and evaluate the future developments of any road landscape. The subject of road landscape has been little studied in Latvia. There are no recommendations on road landscape evaluation. Here we present a methodology for assessing perceptions of road landscapes. We aim to introduce several methods in combination that can be used in road landscape assessment, in order to show possible future developments of the road corridor and its surroundings and to test how potential changes might be perceived by road users. A combination of a case study approach, a scenario method, the use of $3 D$ animations and of a web-based questionnaire survey are presented and discussed in the paper.
\end{abstract}

Keywords: case study method, scenario method, questionnaire survey, road landscape perception, 3D animation

\section{Introduction}

The road landscape is a public space, where, when planning changes to it, principles of democracy, bottom-up development and accounting for the opinion of road users should be followed. A better understanding of what elements road users consider important in the road landscape and what is perceived as scenic can help later in road landscape planning in general, and in scenic route planning [37], for example along tourist routes, in particular.

Landscape perception studies are used to understand how people see and evaluate the landscape from psychological, psychophysical, phenomenological and cognitive approaches $[38 ; 13$; $14 ; 20 ; 34 ; 2]$. Various methods can be used for scenic environment assessment, such as model building [35]. The road landscape character can be assessed with GIS, using map-based indicators and photographs to assess the relationship between landscape and roads [16], or to investigate the relationship of landscape features with scenic preference, using GIS-based visualisations [21]. Movement is one of the key aspects of road landscape perception and it has to be taken into account in road landscape assessment $[18 ; 3 ; 26$ ). Understanding the road landscape as a moving entity is fundamental and in this respect methods need to be different from more standard perception testing tools which rely on static images.

Landscape architecture is a disciplinary field where multi-method approaches to research are normal, borrowing methods developed and tested in many other fields $[9 ; 6]$. The concept of mixing different methods originated in 1959 when Campbell and Fiske used several methods to study the validity of psychological traits. They encouraged others to examine multiple approaches to data collection and analysis [9]. Triangulating data from different sources to seek convergence across qualitative and quantitative methods was proposed by Jick in 1979 [12]. Mixing different types of data emerged from the original concept of triangulation. The integration of different research techniques in one project opens many opportunities for data collection and analysis. As time went on, approaches such as observations and interviews (qualitative data) were combined with surveys (quantitative data) [27]. The introduction and popularity of mixed methods is based on the complementarity of both quantitative and qualitative methods and on obtaining a richer end result than relying on a single method alone. The aim of this paper it to present the various protocols for the research carried out and presented in the doctoral thesis of Kristine Vugule. No results are presented. The research applied case studies, scenarios, 3D modelling, scenario animation development and a questionnaire survey which will be described as a complete multi-method package.

\section{Research strategy}

The overall research strategy applied in the project described here is based on three main elements: a set of case studies, the development and visualisation of future scenarios and the testing of 


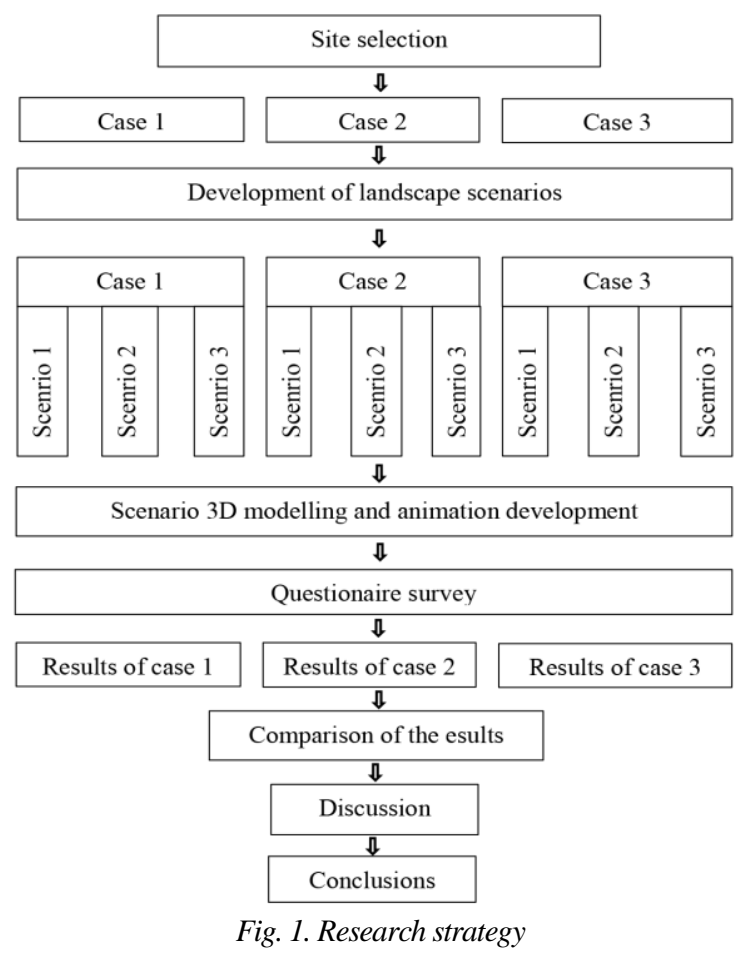

these for preference using a quantitative survey. Overview of the research strategy is given in Figure 1.

The characteristics and main advantages of each will be presented and then the methodology and how they were applied will be presented.

\section{Case studies}

A case study, as defined by Francis, is "a welldocumented and systematic examination of the process, decision making and outcomes of a project that is undertaken to inform future practice, policy, theory and/or education" [11]. It may be broadly defined as a study of a specific event, situation or complex phenomenon investigated in its real-world context [27]. Case study research involves designing the methodology, applying the methods to the case study, analysing the results and disseminating the findings. Case studies can be based on geography, documenting projects within a region, or based on the type of project [11].

The case study approach has been used in many fields including law, business, medicine, engineering, community studies, etc. as a method of education and research [36]. It can be easily used in combination with other methods. Case studies have well-established history in landscape architecture and are a popular research strategy within the discipline. Francis concludes that the case study is a highly appropriate and valuable approach in landscape architecture [11] because almost all research is associated with specific locations with particular contexts and framing conditions. This method can help to answer questions at the intersection of policy and design but have limitations in that the results cannot necessarily be generalised. They are particularly useful in participatory planning, for culturally sensitive design, and for testing emerging concepts. In landscape architecture, many master and $\mathrm{PhD}$ theses use case studies as a basis for analysis because the setting is limited in time and space. They are also effective for communicating the results of landscape architecture projects to a broader public [11] and frequently can be found in academic landscape architecture publications. For example, over the period 2011-2014, cases studies were cited in 78 percent of published peer-reviewed articles in the journal Landscape Research. The Journal of Landscape Architecture (JoLA) includes a section in each issue called 'Under the Sky' dedicated to case studies, and they featured in 32 percent of all peer-reviewed articles in JoLA from 2006 to 2014. Both landscape architecture professionals and academics [27] also present many case studies at conferences.

Within the project on road landscapes, since each section of road is different (although the engineering requirements and standards may be the same) the perception so and solutions to the road landscape are inevitably site-specific. However, as a result of landscape classification, typical cases can be identified, the results of which may be applied more widely to other landscapes of the same type. This is on way of attempting to link the specificities of case studies to a more generalizable set of recommendations.

\section{Scenarios}

The concept of scenarios as a tool for indirectly exploring the future has a long history and can be traced back to the writings of the early philosophers, like Plato. As a strategic planning tool, scenario techniques were originally developed and employed by military strategists, generally in the form of war game simulations [8]. Modern scenario techniques only emerged in the post-war period during the 1960s [6]. Scenarios are now widely used in future studies and include a variety of approaches. Bishop, Hines, and Collins, in their overview of scenario development techniques, identify eight categories of techniques that include a total of 23 variations used to develop scenarios [4]. Since the early 1970s, they have been increasingly used for landscape planning purposes, both at a project level and in research [24;29]. In Latvia, the scenario method has been applied for landscape ecological plan development [15].

Scenarios provide a useful tool to test the dynamics of a landscape and to evaluate the potential consequences of choices in study areas. Scenario-based studies can be divided into normative studies, which seek to identify preferable futures; and descriptive studies, which aim to identify possible futures without regard for specific preferences. In this research on road landscapes the definition of a scenario by Van den Berg and Veeneklaas (1995) is used, where a scenario is 
"description of the current situation, of a possible or desirable future state as well as of the series of events that could lead from the current state of affairs to this future state" [31]. Following this definition, scenarios do not present the most realistic future state, they are not prognoses, predictions, or forecasts. In contrast to forecasts, the scenario concept allows the development of several alternative future landscapes while being aware of the uncertainties associated with each. In extreme cases scenarios can be based not on events which are known to be possible (known knowns) or ones where it is known that variable sexist but there is no knowledge of what they are (known unknowns) but ones which have not been thought of (unknown unknowns or Black Swan Events [28].

\section{Questionnaire surveys}

Interviews and surveys have been widely used for research into landscape. Regarding road landscape or road usage, several studies have investigated the prevalence of a wide range of driving distractions using different forms of interviews: telephone interviews [23], face-toface interviews. Drive along interviews when drivers or passengers can comment landscape they see and point out landscape elements can also be used. Questionnaires may be primarily quantitative, qualitative or a combination. Quantitative surveys, where data are recorded numerically as categories or scales (eg a Likert scale) have the potential for sophisticated statistical analysis including descriptive and predictive statistics. More qualitative surveys allow an in-depth exploration of a phenomenon but no statistical analysis is possible.

The key aspect of a quantitative questionnaire survey is the sampling strategy - whether to obtain a representative, random or quota sample, for example, and the number of respondents directly affects the potential for statistical analysis through the relevant power function (the relationship of the number of variables under test with the characteristics of the sample such as age or gender). Depending on how the survey is administered, it can have the advantage of reaching a reasonably-sized and representative group of people in a short period of time, providing the means to generate data that can be quantified and analysed. The rapid development of survey software and websites on the Internet has led to increased use of web-based surveys, which replace traditional printed survey data collection and on-site studies [19]. Web-based internet surveys have been found to be successful in landscape-related research $[4 ; 33]$ although there can be biases in the samples obtained. Roth found that internet surveys have proved to be an objective and reliable tool for gathering valid data on landscape perception and visual landscape assessments. The results of online scenic quality surveys have a high potential for broader generalizations [22].

\section{Methodology}

\section{Selection of cases}

Cases were chosen as purposive samples [27], which enable conclusions drawn based upon their type in this research. Three road sections on the Latvian major roads A3 (Inčukalns - Valmiera Estonian border) and A7 (Riga - Bauska Lithuanian border) were selected for the research (Fig. 2.). These roads connect the three Baltic States (along the Via Baltica) and are important for tourism development. The length of each road section was $1 \mathrm{~km}$. This length was chosen for practical reasons, due to the limitations on the creation of animated 3D models, representing real-time movement along the road, which was used to present the scenarios and for the questionnaire survey. The width of the road landscape corridor was defined according to the road landscape definition [17] as $2 \mathrm{~km}$ within the animations ( $1 \mathrm{~km}$ either side of the roadline).

\section{Case study descriptions}

The first case area is a section of the A7 major road in Iecava regional community between picket 50.3 and picket 51.3 (pickets indicate the distance from capital Riga in kilometres), representing the open, mostly flat agricultural landscape type characteristic of Latvia. This is a typical agricultural landscape, which belongs to West Zemgale plain, called in the Latvian language, "āraine". This is a type of landscape dominated by arable farmland. The landscape structure is made up of large and wide fields with small stand-alone forest patches and tree groups. It is the most common type of plain cultural landscape that has developed as a result of farming. Because of land amelioration (drainage installation during Soviet collective agricultural times), the natural structure of the landscape has been modified. Very prominent landscape elements with great visual and ecological value typical to rural areas are present here, such as estates and villages, as well as individual trees and tree groups [32].

The second area is a section of the A3 major road in Kocēni regional community from picket 43.5 to picket 44.5, representing the mosaic landscape type. The area is situated in a landscape type known as "mežāre". This is a landscape where agricultural land is interspersed with forest. The relief is undulating or fairly flat and the landscape structure is a mosaic of different patches. Significant landscape elements include farmsteads, natural meadows and groups of trees. Close and mediumclose views are to be found, which terminate at a forest edge or farmhouses surrounded by tree groups [32]. The road landscape has cultural qualities. Hay meadows, pastures used for animal grazing and cultivated fields present the traditional way of land management. The diversity of landscape 


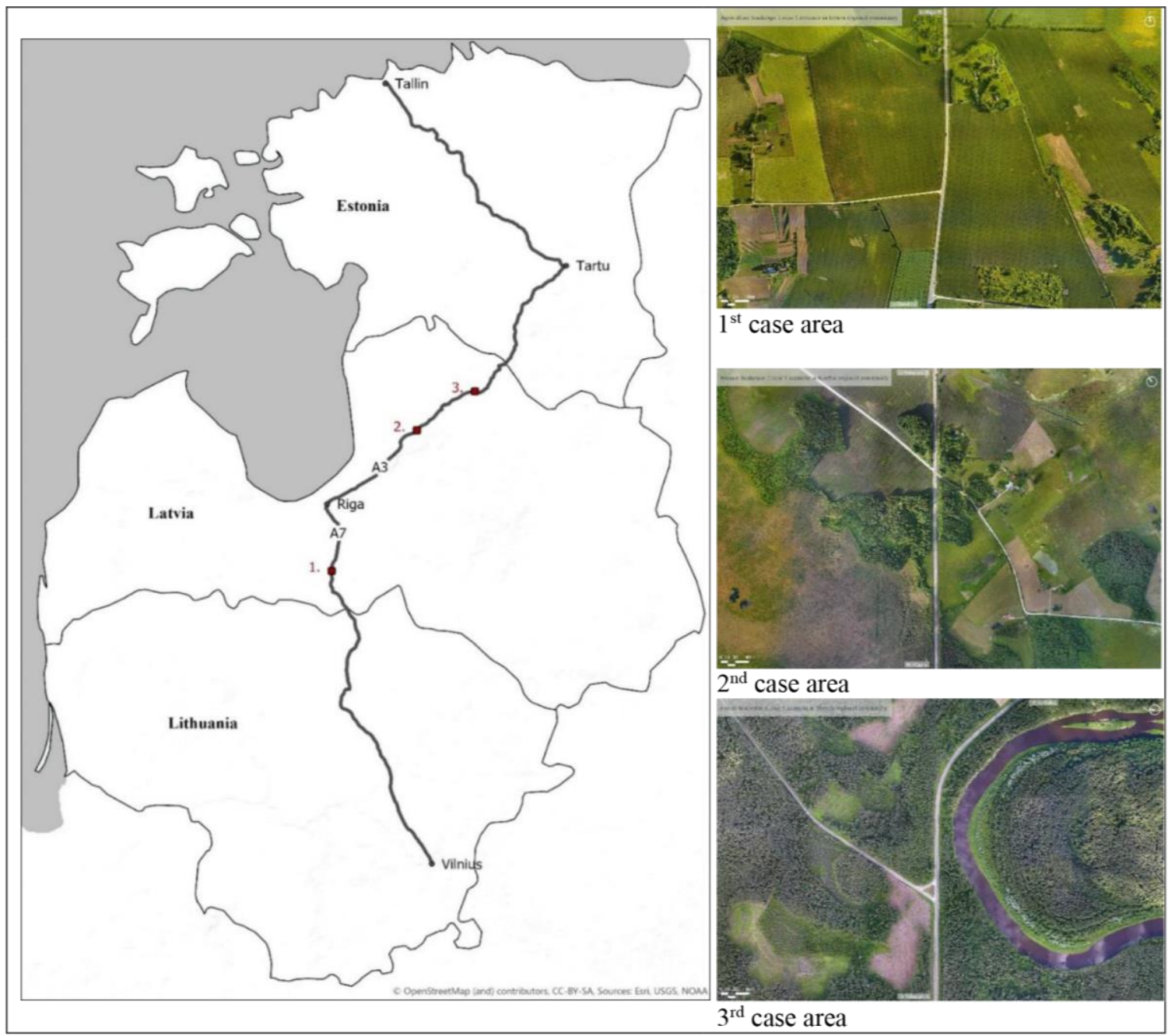

Fig. 2. The location and character of the three case studies used in the research. Sections of case studies marked with red dots on the map of the Baltic States [K.Vugule using OpenStreetMap]

elements and activities is higher than in the previous area due to the more varied landscape structure formed by the open spaces of meadows and enclosures by the forest.

The third case area is a section of the A3 major road in Strenči regional community from picket 92.3 to picket 93.3, representing a forest landscape. The area is situated in a landscape type called "mežaine". characterized by flat terrain and high proportion of forest coverage. The structure of the landscape is made up of large forests, where small agriculture lands form islands. Landscape contrast is determined by the diversity of forest growth conditions - such as different ages and heights of trees as well as felled areas. Close and enclosed views dominate [32]. The area forms part of the North Gauja Protected Landscape Area [1]. The road landscape has high ecological and natural value. The River Gauja flows 50 metres away from the road and if it would be visible from the road this would contribute to its scenic quality.

The application of scenarios in this research illustrate developments that could happen in the case study areas. The set of assumptions applied within each scenario is built on logic, coherence, and consistency. Landscape development scenarios were defined by considering legal provisions and socioeconomic aspects of landscape development. None of the scenarios is designed to be more realistic than others: all are plausible. The road infrastructure has not been changed in any of the scenarios. Roadside management shows standard practice. Road edges are one metre wide. The surface of roads may show some cracks and imperfections normally found on Latvian roads, included to be more realistic. The scenarios therefore focus on the landscape beyond the roadside.

The first scenario in each case presents the existing landscape and acts as a baseline to which alternative scenarios are developed, the second scenario presents a more intensive use of the territory and the third scenario less intensive use of the territory. The proposed scenarios were developed on the current topography but were not planned to represent fully realistic landscape management and design options. 


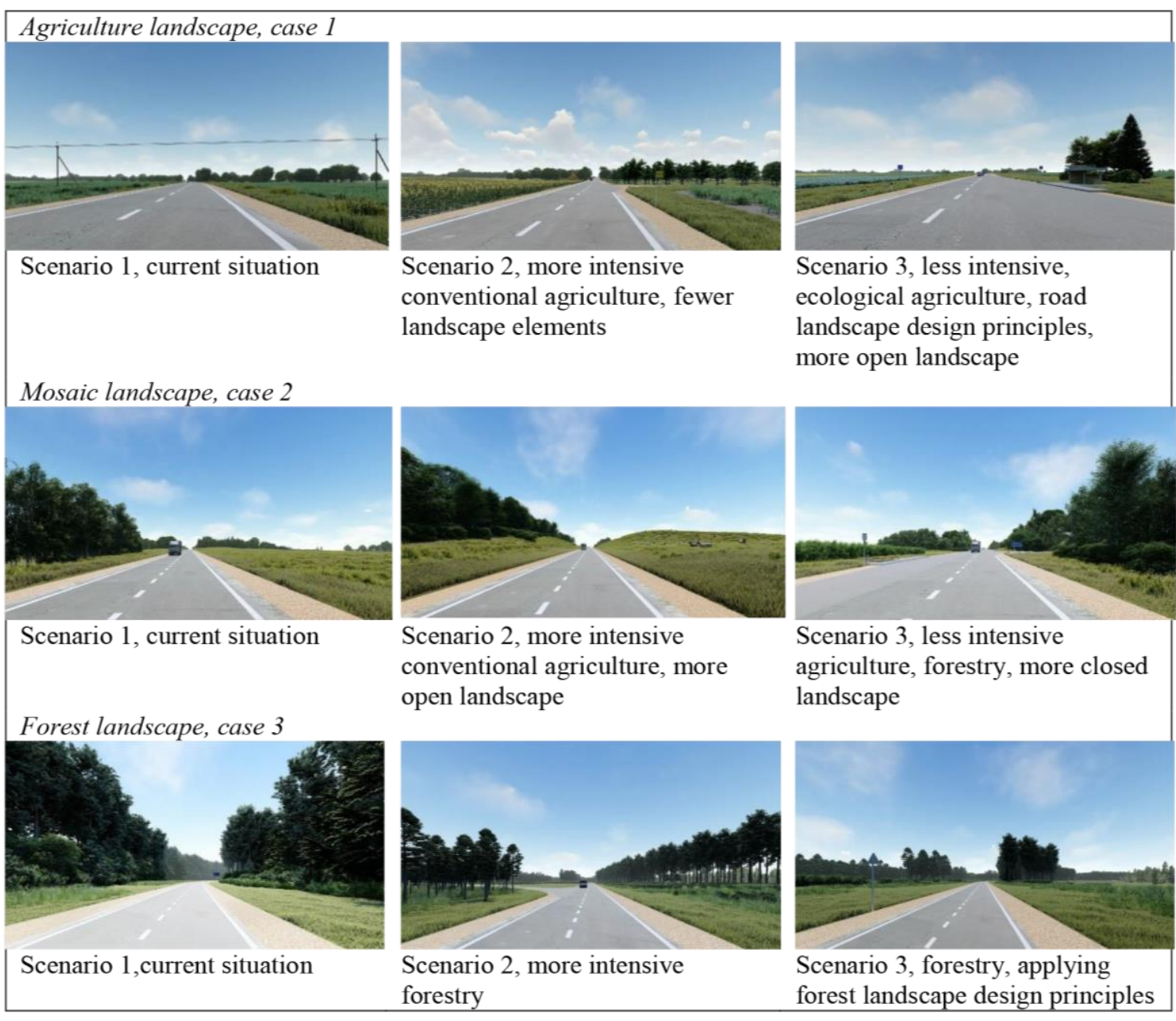

Fig. 3. Snapshots of the landscape of each case study and scenario [K. Vugule material]

To assess the road landscape perception in a more realistic way, through motion, experiencing the landscapes as travellers in a car would, which is an important aspect of road landscape perception, animations of each case area and scenario were created. Three-dimensional computer models were developed for each area using Microsoft Sketchup and Lumion 8 software. Nine animated sequences of driving along the road based on these computer models were developed. The models were based on real data. Point cloud from the LiDAR inventory was used to acquire topography data and georeferenced orthophotomaps. These data were used in 3D model building and animation development. The road user is assumed to observes the landscape while moving along the road at a permitted maximum driving speed of $90 \mathrm{~km} / \mathrm{h}$ with the eye-level at 1100 $\mathrm{mm}$ above the road level (sitting in a typical car). While road landscape should be evaluated in both directions, as the landscape is perceived differently in each driving direction, each animation only depicted movement in one direction along the $1 \mathrm{~km}$ modelled stretch of road through the study area because this was a limitation of the subsequent questionnaire application. If the task of the research was to evaluate the case study areas and offer solutions for their development, then it would be necessary to develop animations in the opposite direction as well but in this research only one direction was used.

The scenario development applied four visual characteristics of road related to traveller's movement along the road - variety, aesthetic of flow, legibility, and orientation [5]. These characteristics of the road landscape were taken into account in the scenario animation development.

Scenario characteristics and snapshots from the designed scenario animation are presented in Figure 3.

\section{Road user survey}

A web-based road user survey was carried out to test the preferences for the scenarios. The intention was to reach a sample of typical road users and to collect data about user preferences on the road landscape and its elements. The internet-based questionnaire instrument was chosen due to the technologies used in the research - the need to present the scenarios as video clips. Firstly, it was necessary to demonstrate road landscape animations and secondly, to reach enough respondents.

The questionnaire was developed and tested first using the first case area. It was pilot tested on two target groups of 14 landscape architects and 
14 ordinary persons. The aim was to test the structure of the survey and to see if the questions were understandable to road user and whether they could recognise positive and negative elements in the road landscape. The results showed that it was necessary to change some terminology and to improve the way they were demonstrated. For example, the YouTube platform that was initially used, reduced the quality of resolution of the animations. The questionnaire was improved and five more animations were then added after the pilot testing. The final version of the survey consisted of 74 questions about nine animations. The questionnaire was prepared in a web-based format using a survey tool created by the research company SolidData which was contracted to carry out the survey data collection according to a specific set of criteria or representativeness. The animations were presented from a www.vimeo.com platform which maintained the high-resolution quality of the videos. Respondents were recruited from a Latvian survey respondent database. The survey was carried out in Latvian. The questionnaire was placed online for two weeks in April 2019. The respondents recruited by the company were given access to the survey and a target quota was obtained by the company who guaranteed the data quality. The questionnaire was completed by 217 respondents, genders being divided equally - 109 females and 108 males.

\section{Processing of data}

In the research 3D animations were developed for case areas in order to present scenarios for possible development of different types of road landscape. Respondents taking part in the questionnaire watched the different animations and answered questions about their perceptions of road landscapes, pointing out their views on the different scenarios. The main findings emerging from the questionnaire were analysed regarding the respondents' assessment of how important is the landscape they see when traveling along the road, as well as landscape attractiveness, the degree of landscape openness, positive and negative elements or features and the feeling of safety in ach animation.

The data from all the three scenario preferences and the ratings of positive and negative road landscape elements in each case were analysed, followed by the comparison of case results. Answers from open questions were grouped by key words and analysed. Statistical data analysis was carried using the Microsoft Excel program. Multi-factor correlation analysis was carried out which did not show a close correlation among the features, thus showing no interdependence of the results. Descriptive statistics and comparative analysis were used. Descriptive statistics were used to describe the general research use and perceptions of research by survey participants. For comparative analysis the ANOVA was used to test whether the differences were statistically significant between different groups or between findings in this survey. Most data were from multiple-choice questions measured on a four or five point Likert scale, which were treated as continuous variables. In the multiple choice questions, options were coded as categorical variables. Pivot tables were used for cross sectional analysis and to visualize results with tables and graphs. All quantitative data were tabulated and are represented in bar charts by the percentages of responses in each category for each item. Nominal data were reported by frequencies. Ordinal or interval data, measured on a five point Likert scale, were reported by means and standard deviations, as well as frequencies.

Visual characteristics of road related to traveller's movement along were evaluated. Variety, a factor identified as a key concept of the visual quality of the road landscape by Tveit et al. (2006), was noticed and mentioned by respondents as a positive feature. From the characteristics regarding the aesthetics of flow, respondents noticed varied and long enough views. Legibility, which is facilitated by visual guidance, good road alignment and simplicity in design, received negative comments from respondents when the road went into a curve or was in a cutting. Much attention was paid to road signs, which help in orientation. Respondents named positive elements 705 times and negative elements 549 times in all scenarios together. The most mentioned positive elements were trees, tree groups, and bushes. The most named negative elements were the ones which can cause danger on the road, such as poor or limited visibility due to trees and bushes close to the road.

\section{Limitations of the research}

The scenario animation method has some limitations. Compared to the traffic simulator, which resembles real-life situations with a possibility to change the focus and angle where one looks, in the animations the landscape was only assessed from the driver's position looking straight ahead. Thus, in the animations, respondents might focus on some things which they do not notice in real life and they were forced to look only at the road ahead.

The use of animations in a web-based survey limits the length of the road section to study or the possibility to assess the landscape from both directions. Animations cannot be too long in order to maintain the attention of respondents. In this research, the average time spent to fill the questionnaire per person was 24.5 minutes. The number of free comments added to the survey forms decreased towards the end of the process, indicating that respondents started to get tired.

There are currently technical limitations of models being too large to demonstrate them online for a web-based survey due to band-width limits, although this is improving year by year. 
The web-based survey method also has limitations, which could have influenced the results. It was recommended at the beginning of the questionnaire to look at the animations on a computer in a full-screen mode, but it is possible that respondents completed it in on a mobile phone or a tablet with a small screen, where it is more difficult to notice differences in the animation design. There were some comments that the animations looked the same.

The road section of $1 \mathrm{~km}$ length is appropriate for landscape assessment using an animation method. It was possible to assess most of the characteristic features of the road except sequences and road alignment. For these characteristics, the road section should be longer. It is essential in road landscape planning to look at the whole route as the road landscape is perceived as one "story" during the whole drive. Road landscapes can be designed for short sections only after analysis and development plan or general guidelines of the whole route have been carried out.

\section{Conclusions}

The case study approach ensured that the research covered the evaluation of road landscapes in the most common landscape types in Latvia.

Development of different future scenarios for each case area provided the opportunity to reach statistically significant conclusions about road landscape qualities, landscape structure, maintenance, and road landscape elements.

The use of the animation method was effective for evaluating how road users see and notice the visual characteristics of the road related to traveller's movement along the road - variety, aesthetic of flow, legibility, and orientation.

The web-based road user survey was effective, and using the panel helped to reach a satisfactory number of respondents in a short time, the results were easy to process and were valid for analyses.

While respondents were not asked to evaluate the road quality, nevertheless, there were many positive and negative comments regarding the quality of road surface, road markings and the width of the road. This shows that it is not necessarily possible to restrict what researchers want respondents to focus on.

\section{References}

1. Aizsargājamo ainavu apvidus "Ziemelgauja" individuālie aizsardzības un izmantošanas noteikumi: LR Ministru kabineta noteikumi Nr. 957. Pieṇemts 20.11.2008. Stājas spēkā 27.11.2008 [online 14.05.2019.]. http://likumi.lv/doc.php?id=184294

2. Bell S. Landscape Pattern, Perception and Process. London: Routledge, 2012, 340 p.

3. Bell S. Design for Outdoor Recration. 2nd Edition. London, UK: Spon Press, 2008, 261p.

4. Bishop P., Hines A., Collins T. The current state of scenario development: an overview of techniques. Foresight, Vol. 9, No. 1, 2007, p. 5-25

5. Blumentrath C., Tveit M. S. Visual characteristics of roads: A literature review of people's perception and Norwegian design practice. Transportation Research Part A: Policy and Practice, Vol. 59, 2014, p. 58-71.

6. Bradfield R., Wright G., Burt G., Cairns G., Van Der Heijden K. The origins and evolution of scenario techniques in long range business planning. Futures, Vol. 37, No. 8, 2005, p. 795-812.

7. Brink van den A., Bruns D., Tobi H., Bell S. Research in Landscape Architecture. Methods and methodology. London and New York: Routledge, 2017, p. 105-118

8. Brown S. (1968). Scenarios in systems analysis. In: E.S. Quade, W.I. Boucher (Eds.). Systems Analysis and Policy Planning: Applications in Defence. New York: American Elsevier Publishing Co., 1968, p. 298-323.

9. Creswell J.W. Research Design: Qualitative, Quantitative, and Mixed Methods Approaches, Los Angeles, CA: Sage, 2014, $273 \mathrm{p}$

10. Deming M.E., Swaffield S. Landscape Architecture Research: Inquiry, Strategy and Design, Hoboken, NJ: John Wiley \& Sons, 2011, 272 p.

11. Francis M. A case study method for landscape architecture. Landscape Journal, No. 20, issue 1, 1999, p. 1-19.

12. Jick T.D. Mixing qualitative and quantitative methods: Triangulation in action. Administrative Science Quarterly, Vol. 24, 1979, p. 602-611.

13. Kaplan R., Kaplan S. The Experience of Nature: a Psychological Perspective. Cambridge: Cambridge University Press, 1989, $340 \mathrm{p}$.

14. Kent R. L. Determining scenic quality along highways: a cognitive approach. Landscape and Urban Planning, Vol. 27, 1993, p. 29-45.

15. Latkovskis P. Ainavu ekologiskā plānošana un tās metodologiskie risinājumi mozaīkveida ainavās. Promocijas darbs. Riga: LU, 2013, 156 p.

16. Martín B., Ortega E., Otero I., Arce R. M. Landscape character assessment with GIS using map-based indicators and photographs in the relationship between landscape and roads. Journal of Environmental Management, Vol. 180, 2016, p. 324-334.

17. Melluma A., Leinerte M. Ainava un cilvēks. Riga: Avots, 1992, 176 p.

18. Mourant R. R., Rockwell T. H. Mapping eye-movement patterns to the visual scene in driving: An exploratory study. Human Factors: The Journal of Human Factors and Ergonomics Society, Vol. 12, No. 1, 1970, p. 81-87.

19. Olwig K. R. Liminality, seasonality and landscape. Landscape Research, Vol. 30, No. 2, 2005, p. 259-271.

20. Palmer J. F. Whither scenic beauty? Visual landscape quality assessment in the 21 st century. Landscape and Urban Planning, Vol. 54 (1-4), 2001, p. 267-281. 
21. Qin X., Meitner M. J., Chamberlaiz B. C., Zhang X., Centre F. S. Estimating Visual Quality of Scenic Highway using GIS and Landscape Visualizations, 2013, 10 p.

22. Roth M. Validating the use of internet survey techniques in visual landscape assessment - an empirical study from Germany. Landscape and Urban Planning, Vol. 78, No. 3, 2006, p. 179-192.

23. Schroeder P., Meyers M., Kostyniuk L. National Survey on Distracted Driving Attitudes and Behaviors - 2012. Report No. DOT HS 811 729. Washington, DC: National Highway Traffic Safety Administration, 2013, 194 p.

24. Shearer A. W. Approaching scenario-based studies: Three perceptions about the future and considerations for landscape planning. Environment and Planning B: Planning and Design, Vol. 32, No. 1, 2005, p. 67-87

25. Sieber S. D. (2002). The integration of fieldwork and survey methods. American Journal of Sociology, Vol. 78, No. 6, p. $1335-1359$.

26. Smirnovs J. Transports un vide. Autoceḷ labiekārtošana. Riga: RTU, 2008, 88 p.

27. Swafield S. Case studies. In: Research in Landscape Architecture: Methods and Methodology. Ed. by A. Brink, D. Bruns, H. Tobi, S. Bell. New York, NY: Routledge, 2017, p. 105-120.

28. Taleb, N. N. The Black Swan: the impact of the highly improbable (2nd ed.). London: Penguin, 2007

29. Tress B., Tress G. Scenario visualisation for participatory landscape planning - a study from Denmark. Landscape and Urban Planning, Vol. 64, 2003, p.161-178.

30. Tveit M., Ode Å., Fry G. Key concepts in a framework for analysing visual landscape character. Landscape Research, Vol. 31, No. 3, 2006, p. 229-255.

31. Veeneklaas F.R., Berg L.M van den. Scenario building: art, craft or just a fashionable whim? In: Scenario Studies for the Rural Environment. Ed. by J.F.T. Schoute, P.A. Finke, F.R Veeneklaas, H.P. Wolfert. Dodrecht: Kluwer Academic Publishers, 1995, p. 11-13.

32. Vides aizsardzības un regionālās attīstības ministrija. Ainavu aizsardzība. Nozares pārskats rajona plānojuma izstrādāšanai. Riga: Jumava, 2000, 91 p.

33. Wherrett J. R. Creating landscape preference models using internet survey techniques. Landscape Research, Vol. 25, No. 1, 2000, p. 79-96.

34. Wolf K. L. Assessing public response to freeway roadsides. Urban Forestry and context-sensitive solutions. Journal of the Transportation Research Board, 2006, p.102-111.

35. Xiao R.-M., Yun W.-G., Xu T.-B. Driving safety on long-even-straight-line road on highland. Journal of Chang'an University. Natural Science Edition, Vol. 27, No. 3, 2007, p. 76-79.

36. Yin R. F. Applications of Case Study Research. Thousand Oaks, CA: Sage Publications, 2011, 264 p.

37. Zheng Y.-T., Yan S., Zha Z.-J., Li Y., Zhou X., Chua T.-S., Jain R. GPSView. ACM Transactions on Multimedia Computing, Communications, and Applications, Vol. 9, No. 1, 2013, p. 1-18.

38. Zube E. H. Perceived land use patterns and landscape values. Landscape Ecology, Vol. 1, No. 1, 1987, p. $37-45$

AUTHORS:

Kristīne Vugule, Dr. arch., guest lecturer and researcher at the Faculty of Environment and Civil Engineering, Department of Landscape Architecture and Planning of the Latvia University of Life Sciences and Technologies.

E-mail: kristine.vugule@1lu.lv

Simon Bell, PhD professor and Chair of department of landscape architecture at the Estonian University of Life Sciences, Associate Director of the OPEN space Research Centre at University of Edinburgh and visiting professor and senior researcher at the Faculty of Environment and Civil Engineering, Department of Landscape Architecture and Planning of the Latvia University of Life Sciences and Technologies since 2012. E-mail: simon.bell@emu.ee

Ilze Stokmane, Dr. oec. in Regional planning, guest associate professor and senior researcher at the Faculty of Environment and Civil Engineering, Department of Landscape Architecture and Planning of the Latvia University of Life Sciences and Technologies.

E-mail: ilze.stokmane@1lu.lv

Kopsavilkums. Mēs katru dienu redzam, izmantojam un mijiedarbojamies ar dažāda veida ainavu. Viens no nozīmīgiem ainavu tipiem, ar kuru saskaramies ikdienā pārvietojoties, gan darba vajadzībām, gan lai cel̦otu, ir ceḷa ainava. Ainava, ko vērojam no cel̦a, rada priekšstatu par jauniem reǵioniem, tā var aicināt mūs izpētīt sīkāk tuvāko apkārtni. Ceḷa ainava ietekmē tādus būtiskus aspektus saistībā ar autoceliem un transporta infrastruktūru, kā vietējo iedzīvotāju dzīves kvalitāte, satiksmes drošība un tūrisma attīstība. Cel̦a ainavas attīstība attiecas gan uz zemes īpašniekiem, gan uz ceḷa lietotājiem, un katram var būt atškiirīgas intereses un izpratne par iespējamo ainavas nākotni un attīstības sekām. Tāpēc ir svarīgi novērtēt, plānot, un apspriest jebkuras ceḷu ainavas turpmāko attīstību. Ceļu ainavas tēma Latvijā ir maz pêtīta, un publikācijā mēs piedāvājam ceḷu ainavu uztveres novērtēšanas metodiku. Raksta mērḳis ir iepazīstināt ar vairākām metodēm, kuras apvienojot var izmantot ceḷa ainavu novērtēšanā, lai parādītu iespējamo ceḷa koridora un tā apkārtnes attīstību nākotnē un pārbaudītu, kā iespējamās izmaiņas uztver ceḷu lietotāji. Tiek aprakstītas sekojošas metodes - gadījumu izpētes pieeja, scenāriju metode, 3D animāciju veidošana un ceḷa lietotāju aptauja. 